\title{
Economic analysis of wind electricity generation in the northern coast of Senegal
}

\author{
B. Ould Bilal ${ }^{1,2,3, \star}$, C.M.F. Kébé ${ }^{1}$, V. Sambou ${ }^{1}$, P.A. Ndiaye ${ }^{1}$, and M. Ndongo ${ }^{3}$ \\ ${ }^{1}$ Centre International de Formation et de Recherche en Energie Solaire (C.I.F.R.E.S)/ESP-UCAD, BP 5085 Dakar Fann, \\ Sénégal \\ 2 École des Mines de Mauritanie (EMiM), BP 5259, Nouakchott, Mauritanie \\ ${ }^{3}$ Centre de Recherche Appliquée aux Energies Renouvelables de l'eau et du froid (CRAER), FST, Université de Nouakchott, \\ BP 5026, Nouakchott, Mauritanie
}

Received: 25 February 2014 / Accepted: 12 June 2014

\begin{abstract}
The main target of this paper is to determine the seasonal features of the wind speed in the northwestern of Senegal and to assess the cost of annual energy output using wind turbines provided from several manufactures. The wind data used for this study were collected in four sites located in the northwestern coast of Senegal and cover the period of one year. The seasonal mean wind speed and the annual distribution curves were obtained by using the Weibull distribution function. A technical assessment of electricity generation from five big wind turbines which power is between $640 \mathrm{~kW}$ and $2000 \mathrm{~kW}$ and from six small wind turbines which power is between $250 \mathrm{~W}$ and $10 \mathrm{~kW}$ were carried out. The results obtained show that the lower cost $(0.0265 € / \mathrm{kWh}$ in Sokhar $)$ was observed for the wind turbine Ecotècnia 62 . The highest cost was $0.5103 € / \mathrm{kWh}$ (in Gandon) observed for the technology of Alize. All wind turbines was better suited to the site of Sokhar with the highest capacity factor and the lowest cost of output energy.
\end{abstract}

Keywords: Wind energy, Weibull distribution, wind turbine, electricity generation, analysis cost

\section{Introduction}

The use of the fossil fuels have been creating serious environmental problems, such as gas emissions, air pollution and climate changes thereby making current energy trends to be unsustainable thus necessitating a better balance between energy, economics, development and protection of the environment [1]. Renewable energy sources (wind, solar, hydro, biomass, etc.) are inexhaustible, clean, free and offer many environmental and economical benefits in contrast to conventional energy sources [2]. So, wind energy appears as a clean and good solution to cope with a great part of this energy demand [3]. Recently, many researchers [4-7] have studied the wind energy resources in the sites all over the world. In Senegal, the development of new wind projects continues to be hampered by the lack of knowledge of wind potential and the absence of reliable and accurate wind resource data in many parts of the country. Recent studies [8-14] have concluded that the best area to use wind energy is along the coastal areas of Senegal. However, we have a little knowledge about the seasonal variation of the wind speed and the economic analysis of the wind electricity generation by using wind turbines. So, the contribution of this paper is to evaluate the wind power potential by determining the seasonal effect on the characteristics of the wind speed in four sites

^ Correspondence: boudy_bilal@yahoo.fr
(Kayar, Potou, Gandon and Sakhor) located in the northwestern coast of Senegal and to assess the cost of wind electricity produced by using wind turbines which with different size. This study allows to choose a suitable wind turbines with the high performances and lower costs of kWh produced.

\section{Material and methods}

\subsection{Description of the sites and data collected}

In the present study, four metrological stations were installed in the sites of Kayar, Potou, Gandon, and Sakhor located along the northwestern coast of Senegal. Table 1 gives the locations of these meteorological stations, the period of collect and coverage rate of data for each site. These stations were equipped with a data acquisition system which, records every $10 \mathrm{~min}$ the average, maximum and minimum values for each sensor. The evaluation of the collected data in the sites has showed that the coverage rate was between $96 \%$ and $100 \%$.

\subsection{Theoretical models}

(1) Mean wind speed: In the present study, the wind speeds data measured every ten minutes for one year in each site 
Table 1. Characteristics of the meteorological stations.

\begin{tabular}{cccccc}
\hline Site & Latitude north $\left(^{\circ}\right)$ & Longitude west $\left(^{\circ}\right)$ & Elevation $(\mathrm{m})$ & Measures period & Coverage rate $(\%)$ \\
\hline Kayar & 14.92 & 17.12 & 06.00 & August 2007 to July 2008 & 100 \\
Potou & 15.72 & 16.50 & 21.00 & August 2007 to July 2008 & 100 \\
Gondon & 15.96 & 16.45 & 05.00 & Jun 2004 to May 2005 & 99 \\
Sakhor & 14.23 & 16.45 & 03.00 & November 2007 to October 2008 & 96 \\
\hline
\end{tabular}

were used to calculate the wind potential. The seasonal mean wind speed values were calculated by using equation (1), [15]

$$
v_{m}=\frac{1}{n} \sum_{i=1}^{n} v_{i}
$$

where $n$ is the observation number and $v_{i}$ is the wind speed in time stage $i$.

(2) Weibull distribution: Weibull distribution has been commonly used in literature to express the wind speed distribution and to estimate the wind power density. The Weibull distribution is a good match with the experimental data. The probability density function of Weibull is given by equation (2) [16]:

$$
f(v)=\frac{k}{A}\left(\frac{v}{A}\right)^{k-1} \exp \left(-\left(\frac{v}{A}\right)^{k}\right)
$$

where $A$ and $k$ are respectively the scale and the shape parameters of Weibull, which can be determined by using the Maximum likelihood method equations (3) and (4) [17]

$$
\begin{gathered}
k=\left(\left(\frac{\sum_{i=1}^{n} v_{i}^{k} \ln \left(v_{i}\right)}{\sum_{i} v_{i}^{k}}\right)-\left(\frac{\sum_{i=1}^{n} \ln \left(v_{i}\right)}{n}\right)\right)^{-1} \\
A=\left(\frac{\sum_{i=1}^{n} v_{i}^{k}}{n}\right)^{\frac{1}{k}} .
\end{gathered}
$$

Smaller $k$ values correspond to more variable (more gusty) winds and the higher $A$ values correspond to a good potential.

(3) Wind power density: The long-term wind speed distribution $f(v)$ is combined with the available wind power to give the average wind power density, which can be expressed as follows [18]:

$$
\bar{P}=\frac{1}{2} \rho A^{3} \Gamma\left(1+\frac{3}{k}\right)
$$

where $\Gamma(x)$ is the gamma function of $(x)$ given by:

$$
\Gamma(x)=\int_{\grave{a}}^{\infty} t^{x-1} e^{-t} d t .
$$

(4) Extrapolation of the wind speed with the height: the wind speed was collected at 20 and $30 \mathrm{~m}$ of high in Kayar and Potou, at 20 and $40 \mathrm{~m}$ in Gandon, and at 7 and $12 \mathrm{~m}$ above ground level in Sakhor. For wind projects, it is necessary to estimate the wind speed at the wind turbine hub height. According to the literature, the most commonly used method to adjust the wind speed from one level to another is the power law method [19] expressed by:

$$
v=v_{0}\left(\frac{h}{h_{0}}\right)^{\alpha}
$$

where $v_{0}$ is the reference wind speed $(\mathrm{m} / \mathrm{s}), h_{0}$ is the reference height $(\mathrm{m}), v$ is the wind speed $(\mathrm{m} / \mathrm{s})$ to be determined for the desired height $h$, and $\alpha$ is the roughness factor estimated by using the wind speed measurement at the two altitudes.

\subsection{Wind turbine output model}

Major wind turbine manufacturers give the power curves of their products in their technical notes. So, it is simple to estimate the power output of any wind turbine when a series of measurements were conducted in the studied site. However, in several cases only the probability distribution function is available. In this situation the power output from the wind turbine can be expressed as [20]:

$$
P_{w, a v g}=\int_{0}^{+\infty} P_{w} f(v) d v
$$

where $f(v)$ is the Weibull distribution given by equation (1), $P_{w}$ is the electrical power ouput of the turbine.

A model for electrical power output from the wind turbine is expressed as follows [21]:

$$
\begin{aligned}
& P_{w}=0 \quad\left(v<v_{c i}\right) \\
& P_{w}=P_{r} \frac{v^{k}-v_{c i}^{k}}{v_{r}^{k}-v_{c i}^{k}} \quad\left(v_{c i}<\mathrm{v}<v_{r}\right) \\
& P_{w}=P_{r} \quad\left(v_{r}<v<v_{c o}\right) \\
& P_{w}=0 \quad\left(v>v_{c o}\right)
\end{aligned}
$$

where $\operatorname{Pr}$ is the rated electrical power $(W), v_{c i}$ is the cut-in speed $(\mathrm{m} / \mathrm{s}), v_{r}$ is the rated speed $(\mathrm{m} / \mathrm{s}) v_{c o}$ is the cut-off speed $(\mathrm{m} / \mathrm{s})$ and $k$ is the unitless Weibull shape parameter defined by (3). 
Table 2. Seasonal mean wind speed $(\mathrm{m} / \mathrm{s})$ in the all sites at various heights and the roughness factor.

\begin{tabular}{lccccc}
\hline & Season & Dry season & Rainy season & All data & Roughness factor $(-)$ \\
\hline \multirow{3}{*}{ Site of Potou } & Height of 30 & 5.65 & 4.74 & 5.27 & \multirow{2}{*}{0.23} \\
& Height of 20 & 5.09 & 4.38 & 4.8 & \multirow{2}{*}{0.25} \\
& Height of 30 & 5.06 & 4.36 & 4.77 & \multirow{2}{*}{0.27} \\
\multirow{5}{*}{ Site of Kayar Gandon } & Height of 20 & 4.55 & 3.99 & 4.32 & \\
& Height of 40 & 5.56 & 4.78 & 5.24 & 0.33 \\
& Height of 20 & 4.52 & 4.09 & 4.34 & \\
& Height of 12 & 4.85 & 3.88 & 4.49 & 3.72 \\
\hline
\end{tabular}

Substituting equations (2) and (9) into equation (8) yields equation (10) [20,21]:

$$
P_{w, a v g}=P_{r}\left\{\frac{\exp \left[-\left(\frac{v_{c i}}{A}\right)^{k}\right]-\exp \left[-\left(\frac{v_{r}}{A}\right)^{k}\right]}{\left(\frac{v_{r}}{A}\right)^{k}-\left(\frac{v_{c i}}{A}\right)^{k}} .\right.
$$

For small-scale wind turbines, the cut-in speed and nominal speed are in general smaller, and the wind turbines can operate easily even when the wind speed is not very high. The average energy output $E_{\text {out }}$ for a period of time $\Delta t$ will be calculated as:

$$
E_{\text {out }}=P_{w, \text { avg }} \Delta t .
$$

The capacity factor $C_{f}$ is one of the performance parameters of wind turbines that both the user and manufacturer need to know. It represents the fraction of the total energy delivered over a period $\left(E_{\text {out }}\right)$ divided by the maximum energy that could have been delivered if the wind turbine was used at maximum capacity over the all period. For the period of a year, the maximum energy output can be calculated by [17]:

$$
E r=8.760 P r .
$$

The capacity factor $\left(C_{f}\right)$ which is one of the parameters used to estimate the performance of wind turbines, can be computed as:

$$
C_{f}=\frac{E_{\text {out }}}{E_{r}} .
$$

\subsection{Economic analysis}

While adding up costs over time is better than simply comparing initial capital costs, a mathematical method called "the present value of costs" $(P V C)$ analysis takes into account the fact that the value of money changes over time. The following assumptions are used to determine the present value of electricity costs [22].

- Investment $(I)$ includes the turbine price plus its $20 \%$ for the civil work and other connections.
- Operation, maintenance and repair cost $\left(C_{\text {omr }}\right)$ was considered to be $30 \%$ of the annual cost of the wind turbine (machine price/lifetime).

- The life time of the wind turbine $(t)$ was assumed to be 20 years.

- The interest rate $(r)$ and inflation rate $(i)$ were taken to be $7.5 \%$ and $2 \%$, respectively.

- Scrap value $S$ was taken to be $10 \%$ of the wind turbine price and civil work. The present value of costs $(P V C)$ is given by equation (13):

$$
\begin{aligned}
& P V C=I+\operatorname{Comr}\left(\frac{1+i}{r-i}\right)\left[1-\left(\frac{1+i}{1+r}\right)^{t}\right] \\
& -S\left(\frac{1+i}{1+r}\right)^{t} \text {. }
\end{aligned}
$$

\section{Results and discussion}

\subsection{Wind regimes in the all sites}

The wind regimes in the sites of Kayar, Potou, Gandon and Sakhor were determined by using the data collected at two heights for each site. The monthly average wind speed was calculated. Two distinct seasons were noticed in these regions: a dry season (November-May) and a rainy season (June-October). In the all sites, the results show that the dry season was characterized by strong wind regimes in contrast the rainy season is characterized by a lower mean wind speed. For example, the average wind speed, in the site of Potou, was $5.65 \mathrm{~m} / \mathrm{s}$ and $4.74 \mathrm{~m} / \mathrm{s}$ for the dry and the rainy season respectively. Thus a wind turbine installed in these regions will product more energy during the dry season than during the rainy season. The annual mean wind speed was $4.80 \mathrm{~m} / \mathrm{s}, 4.32 \mathrm{~m} / \mathrm{s}$ and $4.34 \mathrm{~m} / \mathrm{s}$ in the sites of Potou, Kayar and Gandon at $20 \mathrm{~m}$ of high; it was 4.49 in Sakhor at the height of $12 \mathrm{~m}$ (Tab. 2).

The mean wind speed was directly calculated at the hub height of the wind turbine. This is done by using equation (7) for the four selected stations. The roughness factor was of $0.23,0.25,0.27$ and 0.33 in Potou, Kayar, Gandon and Sakhor respectively. These roughness factors were used to calculate the mean wind speed and the Weibull parameters at the height of the wind turbines hub so as to estimate the electricity generation, then the cost of delivered electricity. 

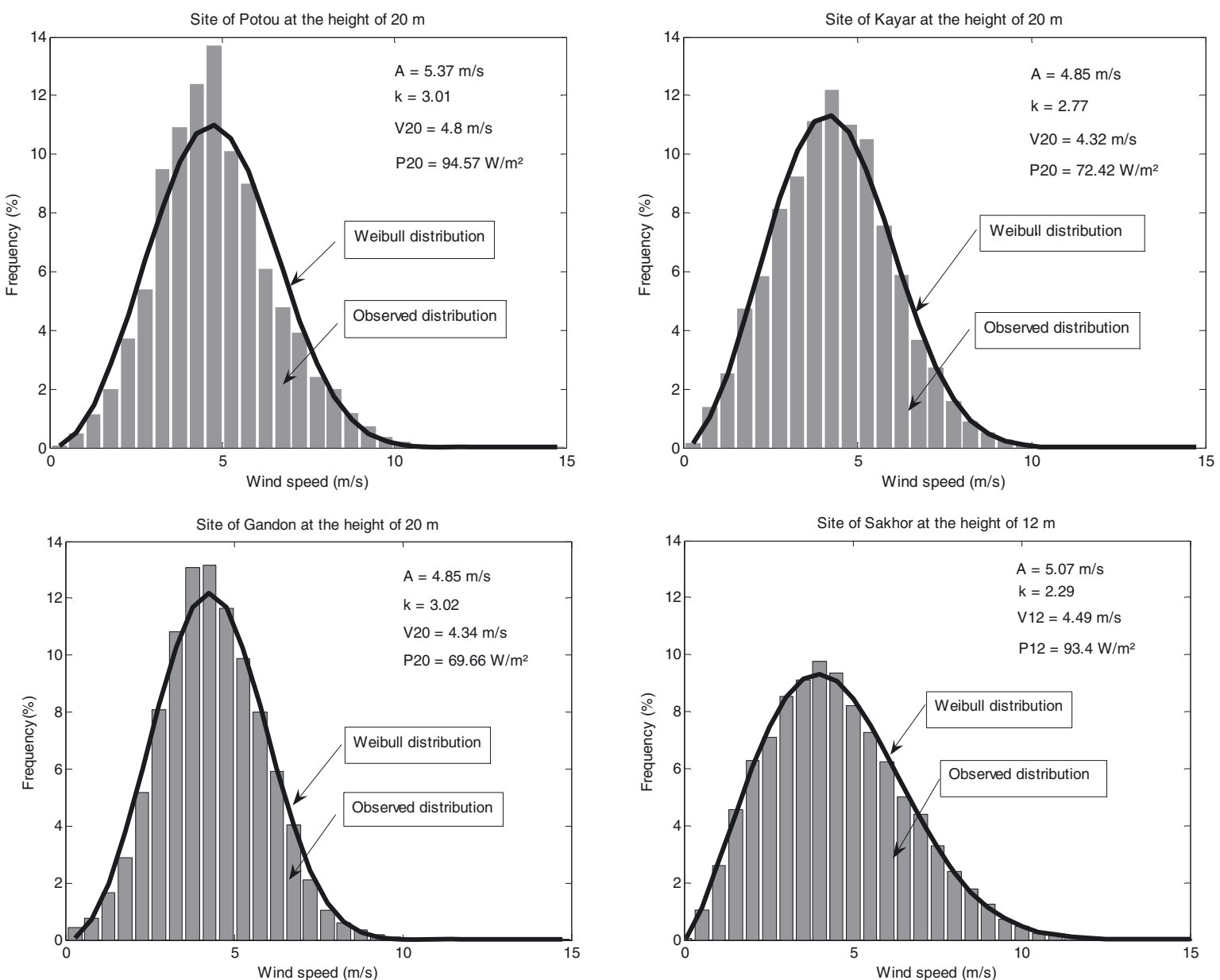

Fig. 1. Weibull and observed distribution in the all sites.

Table 3. Seasonal weibull parameters and power density.

\begin{tabular}{|c|c|c|c|c|}
\hline Season & & Dry season & Rainy season & All data \\
\hline \multirow{5}{*}{ Potou at $20 \mathrm{~m}$} & $A(\mathrm{~m} / \mathrm{s})$ & 5.45 & 4.92 & 5.37 \\
\hline & $k$ & 3.33 & 2.9 & 3.01 \\
\hline & $P\left(\mathrm{~W} / \mathrm{m}^{2}\right)$ & 108.15 & 75.97 & 94.57 \\
\hline & $A(\mathrm{~m} / \mathrm{s})$ & 5.09 & 4.48 & 4.85 \\
\hline & $k$ & 3.02 & 2.73 & 2.77 \\
\hline \multirow[t]{2}{*}{ Kayar at $20 \mathrm{~m}$} & $P\left(\mathrm{~W} / \mathrm{m}^{2}\right)$ & 81.61 & 59.01 & 72.42 \\
\hline & $A(\mathrm{~m} / \mathrm{s})$ & 5.02 & 4.86 & 4.85 \\
\hline \multirow{4}{*}{ Gandon at $20 \mathrm{~m}$} & $k$ & 3.44 & 2.67 & 3.02 \\
\hline & $P\left(\mathrm{~W} / \mathrm{m}^{2}\right)$ & 74.87 & 78.32 & 69.66 \\
\hline & $A(\mathrm{~m} / \mathrm{s})$ & 5.64 & 4.39 & 5.07 \\
\hline & $k$ & 2.61 & 2.21 & 2.29 \\
\hline Sakhor at $12 \mathrm{~m}$ & $P\left(\mathrm{~W} / \mathrm{m}^{2}\right)$ & 108.68 & 67.81 & 93.4 \\
\hline
\end{tabular}

The statistical analysis of the wind speed has been carried out through determining the distribution and the Weibull parameters. The observed and Weibull distribution were determined using collected data on the sites of Potou, Kayar, Gandon and Sakhor. Figure 1 shows a good corresponding between the observed and the Weibull distribution. This study, also, made it possible to determine the seasonal Weibull parameters and the power density for the all height of measures. Table 3 gives the results obtained at the height of $20 \mathrm{~m}$ in the site of Kayar,
Potou and Gandon and at $12 \mathrm{~m}$ for the site of Sakhor. The seasonal mean scale parameter was calculated. It was $5.64 \mathrm{~m} / \mathrm{s}$ for the dry season and was $4.39 \mathrm{~m} / \mathrm{s}$ for the rainy season in the site of Sakhor at $12 \mathrm{~m}$. The corresponding power density was $108.68 \mathrm{~W} / \mathrm{m}^{2}$ and $67.81 \mathrm{~W} / \mathrm{m}^{2}$ for the dry season and for the rainy season respectively. The annual power density obtained in the all sites was $94.57 \mathrm{~W} / \mathrm{m}^{2}, 72.42 \mathrm{~W} / \mathrm{m}^{2}, 69.66 \mathrm{~W} / \mathrm{m}^{2}$ in the sites of Potou, Kayar, Gandon respectively and $93.40 \mathrm{~W} / \mathrm{m}^{2}$ in Sakhor. 
Table 4. Characteristics of commercial wind turbines from several manufactures.

\begin{tabular}{|c|c|c|c|c|c|c|c|}
\hline $\begin{array}{l}\text { Description of the wind } \\
\text { turbine }\end{array}$ & $\begin{array}{l}\text { Rated power } \\
\quad \operatorname{Pr}(\mathrm{kW})\end{array}$ & $\begin{array}{l}\text { Sept area } \\
S\left(\mathrm{~m}^{2}\right)\end{array}$ & $\begin{array}{l}\text { Cut-in speed } \\
V_{c i}(\mathrm{~m} / \mathrm{s})\end{array}$ & $\begin{array}{c}\text { Rated speed } \\
V_{r}(\mathrm{~m} / \mathrm{s})\end{array}$ & $\begin{array}{l}\text { Cut-off speed } \\
V_{c o}(\mathrm{~m} / \mathrm{s})\end{array}$ & $\begin{array}{l}\text { Hub height } \\
(\mathrm{m})\end{array}$ & $\begin{array}{c}\text { Cost } \\
(€)\end{array}$ \\
\hline Ecotècnia 44 & 640 & 1521 & 4 & 14.5 & 15 & 45 & 478005 \\
\hline Ecotècnia 48 & 750 & 1838 & 4 & 14.5 & 25 & 45 & 515771 \\
\hline Ecotècnia 62 & 1250 & 3019 & 3 & 13.5 & 25 & 60 & 1049700 \\
\hline Ecotècnia 80 & 1670 & 5027 & 3 & 14 & 25 & 70 & 1469800 \\
\hline Repower MM82 & 2000 & 5278 & 4 & 13 & 25 & 100 & 1850000 \\
\hline EolSenegal 500 & 0.50 & 7.06 & 2 & 9 & 12 & 18 & 3051 \\
\hline Yellow Sand & 0.30 & 4.52 & 3 & 8 & 15 & 12 & 2615 \\
\hline Montana & 5.60 & 19.6 & 2.5 & 14 & 25 & 12 & 8870 \\
\hline Aircon 10 & 10.00 & 39.6 & 2.5 & 11 & 35 & 18 & 37000 \\
\hline Alize & 10.00 & 38.5 & 3 & 12 & 25 & 18 & 32455 \\
\hline BW Excel & 10.00 & 38.5 & 3.5 & 13 & 25 & 18 & 19000 \\
\hline
\end{tabular}

Table 5. Yearly capacity factor and output energy of the eleven different commercial wind turbines in the all sites.

\begin{tabular}{|c|c|c|c|c|c|c|c|c|}
\hline \multirow[b]{2}{*}{$\begin{array}{l}\text { Type of wind } \\
\text { turbine }\end{array}$} & \multicolumn{2}{|c|}{ Kayar } & \multicolumn{2}{|c|}{ Potou } & \multicolumn{2}{|c|}{ Gandon } & \multicolumn{2}{|c|}{ Sakhor } \\
\hline & $\begin{array}{c}\text { Energy output } \\
\text { (kWh/year) }\end{array}$ & $\begin{array}{c}\text { Capacity } \\
\text { factor }(\%)\end{array}$ & $\begin{array}{c}\text { Energy output } \\
\text { (kWh/year) }\end{array}$ & $\begin{array}{c}\text { Capacity } \\
\text { factor }(\%)\end{array}$ & $\begin{array}{c}\text { Energy output } \\
(\mathrm{kWh} / \text { year })\end{array}$ & $\begin{array}{c}\text { Capacity } \\
\text { factor }(\%)\end{array}$ & $\begin{array}{c}\text { Energy output } \\
\text { (kWh/year) }\end{array}$ & $\begin{array}{c}\text { Capacity } \\
\text { factor }(\%)\end{array}$ \\
\hline Ecotècnia 44 & 294110 & $5 \%$ & 605600 & $11 \%$ & 219690 & $4 \%$ & 1076300 & $20 \%$ \\
\hline Ecotècnia 48 & 344660 & $5 \%$ & 712810 & $11 \%$ & 257450 & $4 \%$ & 1340500 & $20 \%$ \\
\hline Ecotècnia 62 & 841490 & $8 \%$ & 1618000 & $15 \%$ & 636020 & $6 \%$ & 2815400 & $26 \%$ \\
\hline Ecotècnia 80 & 1008600 & $7 \%$ & 1977700 & $14 \%$ & 750360 & $5 \%$ & 3484100 & $24 \%$ \\
\hline Repower & 1279500 & $7 \%$ & 2498600 & $14 \%$ & 1000900 & $6 \%$ & 4517900 & $26 \%$ \\
\hline EolSenegal 500 & 733 & $17 \%$ & 1296 & $30 \%$ & 634 & $14 \%$ & 1470 & $34 \%$ \\
\hline Yellow Sand & 527 & $20 \%$ & 856 & $33 \%$ & 474 & $18 \%$ & 1015 & $39 \%$ \\
\hline Montana & 2238 & $5 \%$ & 5944 & $12 \%$ & 1742 & $4 \%$ & 6247 & $13 \%$ \\
\hline Aircon 10 & 7857 & $9 \%$ & 17294 & $20 \%$ & 6481 & $7 \%$ & 19282 & $22 \%$ \\
\hline Alize & 5589 & $6 \%$ & 13477 & $15 \%$ & 4527 & $5 \%$ & 15029 & $17 \%$ \\
\hline BW Excel & 3909 & $4 \%$ & 10410 & $10 \%$ & 3103 & $4 \%$ & 11627 & $12 \%$ \\
\hline
\end{tabular}

\subsection{Estimation of energy output and cost analysis}

(1) Wind turbines characteristics: the features of the selected wind turbines from several manufactures are given in Table 4 [23]. The rated power of these wind turbines is between 640 and $2000 \mathrm{~kW}$ for the big wind turbine and varies between $300 \mathrm{~W}$ and $10 \mathrm{~kW}$ for the small wind turbines. For the big wind turbine, the Cut-in speed varies between $3-4 \mathrm{~m} / \mathrm{s}$ and the rated speed is between $13-14.50 \mathrm{~m} / \mathrm{s}$ in contrast for the small wind turbines, the cut-in speed varies between $2-3.5 \mathrm{~m} / \mathrm{s}$ and the rated speed is between $8-14 \mathrm{~m} / \mathrm{s}$. These wind turbines were used to study their performance by calculating the output energy, the capacity factor and the electricity cost in the all site so as to choose a suitable wind turbine for electricity generation to grid connection or for isolated application.

(2) Cost analysis: the annual energy output and capacity factor for large and small different wind turbines were calculated for the four stations. The results obtained were given in Table 5 . The highest capacity factor for the all wind turbines is obtained in the site of Sakhor. The values were between 12\% (BW-Excel) and 39\% (Yellow-Sand). In contrast in the site of Gandon, the capacity factor was lowest and varies between $4 \%$ and $18 \%$ (Tab. 5). It is noted that the capacity factor was highest for the wind turbine Yellow-Sand in the all site and was lowest for the wind turbine BW-Excel in the all sites (Tab. 5). That is because of the wind turbine Yellow-Sand has the lowest nominal speed in contrast of the BW-Excel which the nominal speed is greater.

It can, also, be noted that the energy output was greater for the large wind turbines than for the small wind turbines. That is because of the size of these wind turbines.

The present value of costs $(P V C)$ for each wind turbine was calculated by substituting technical data of the chosen wind turbines in equation (14). The cost of electricity for each wind turbine is obtained dividing the $P V C$ by the total energy output over the life time (20 years) of the wind turbines.

The results obtained are seen in Table 6 . The cost of the energy output from the all wind turbines was better in the site of Sakhor than in the other sites. 
Table 6. PVC of the eleven different commercial wind turbines and the yearly output energy cost in the all sites (€/kwh).

\begin{tabular}{lccccc}
\hline & $P V C(€)$ & \multicolumn{4}{c}{ Cost $(€ / \mathrm{kWh})$} \\
\cline { 3 - 6 } Type of wind turbine & & Kayar & Potou & Gandon & Sakhor \\
\hline Ecotècnia 44 & 680480 & 0.1157 & 0.0562 & 0.1549 & 0.0316 \\
Ecotècnia 48 & 734250 & 0.1065 & 0.0515 & 0.1426 & 0.0274 \\
Ecotècnia 62 & 1494300 & 0.0888 & 0.0462 & 0.1175 & 0.0265 \\
Ecotècnia 80 & 2092400 & 0.1037 & 0.0529 & 0.1394 & 0.0300 \\
Repower & 2633600 & 0.1029 & 0.0527 & 0.1316 & 0.0291 \\
EolSenegal 500 & 4346 & 0.2963 & 0.1677 & 0.3730 & 0.1479 \\
Yellow Sand & 3723 & 0.3531 & 0.2174 & 0.3931 & 0.1833 \\
Montana & 12627 & 0.2821 & 0.1062 & 0.3625 & 0.1011 \\
Aircon 10 & 52673 & 0.3352 & 0.1523 & 0.4064 & 0.1366 \\
Alize & 46203 & 0.4134 & 0.1714 & 0.5103 & 0.1537 \\
BW Excel & 27048 & 0.3460 & 0.1299 & 0.4358 & 0.1163 \\
\hline
\end{tabular}

It was between $0.0265 € / \mathrm{kWh}$ and $0.1833 € / \mathrm{kWh}$. However, the highest cost was noted for the site of Gandon. It was between $0.1175 € / \mathrm{kWh}$ and $0.5103 € / \mathrm{kWh}$. The fact that the cost of electricity generated was better for Sakhor than the rest of sites is due to the wind potential which was greater for Sakhor than the rest of the sites.

The wind turbine Ecotècnia-62 presented the best cost of $\mathrm{kWh}$ compared to the all big wind turbines. Wheireas, the cost of the kWh was the better for Montana compared to the all other small wind turbines. It can, also, be noted that the wind turbine Yellow-Sand which the capacity factor was better than the other small wind turbine present the high cost in the site of Sokhar $(0.1833 € / \mathrm{kWh})$ compared to the rest of the small wind turbines. That because of his lowest energy output associate to his size. However, this wind turbine can operate more on the sites.

\section{Conclusion}

In this study, the wind speed and the wind power density were determined for the period of one year in Potou, Kayar, Gandon and Sakhor located in the northwestern coast of Senegal. The wind speed frequency distribution of locations was found by using Weibull distribution functions. From this statistical data analysis and calculations of electricity generation, it can be concluded that:

- Two distinct seasons are noticed in these regions: a dry season (November-May) and a rainy season (JuneOctober). The dry season was characterized by strong wind regimes; whereas, the rainy season was subjected to lower mean wind speeds.

- The annual mean wind speed for the period of a year was obtained as $4.80 \mathrm{~m} / \mathrm{s}, 4.32 \mathrm{~m} / \mathrm{s}, 4.34 \mathrm{~m} / \mathrm{s}$ in the sites of Potou, Kayar, Gandon at the height of $20 \mathrm{~m}$. It was $4.45 \mathrm{~m} / \mathrm{s}$ in the site of Sakhor at $12 \mathrm{~m}$ of height. The corresponding power density was $94.57 \mathrm{~W} / \mathrm{m}^{2}, 72.42 \mathrm{~W} / \mathrm{m}^{2}, 69.66 \mathrm{~W} / \mathrm{m}^{2}$, and $93.40 \mathrm{~W} / \mathrm{m}^{2}$ respectively.
- The performance study of the all wind turbines was achieved in the all sites through determining the factor capacity and the energy output. The all wind turbines have the best capacity factor in the site of Sakhor in which the electricity cost was, also, better. The lowest capacity factor was observed in the site of Gandon for the all wind turbines.

The best wind turbine to use is the Ecotècnia- 62 which the cost of the output energy was better in the all sites for grid connection. Montana was the best for the isolated applications.

It is important to extend this study to other sites from Senegal and the sub region in order to achieve a wind map and a producible energy map.

\section{References}

1. I. Fyrippis, P.J. Axaopoulos, G. Panayiotou, Wind energy potential assessment in Naxos Island, Greece. Appl. Energ. 7, 577-586 (2010)

2. S.A. Akdag, A. Dinler, A new method to estimate Weibull parameters for wind energy applications, Energ. Convers. Manag. 50, 1761-1766 (2009)

3. S.P. Breton, G. Moe, Status, plans and technologies for offshore wind turbines in Europe and North America, Renew. Energ. 34, 646-654 (2009)

4. U. Irfan, C. Qamar-uz-Zaman, J.C. Andrew, An evaluation of wind energy potential at Kati Bandar, Pakistan, Renew. Sust. Energ. Rev. 14, 856-861 (2010)

5. O. Ahmed, D. Hanane, S. Roberto, M. Abdelaziz, Monthly and seasonal assessment of wind energy characteristics at four monitored locations in Liguria region (Italy), Renew. Sust. Energ. Rev. 14, 1959-1968 (2010)

6. B.W. Raichle, W.R. Carson, Wind resource assessment of the Southern Appala- chian Ridges in the Southeastern United States, Renew. Sust. Energ. Rev. 13, 1104-1110 (2009)

7. M. Ali, Feasibility study of harnessing wind energy for turbine installation in province of Yazd in Iran, Renew. Sust. Energ. Rev. 14, 93-111 (2010) 
8. P. Ndiaye, C. Kraif, L. Protin, G. Fleury, Study and modelling of the wind power potential on the site in Dakar by a microcomputer, Electrical and power systems modelling and simulation (1989), pp. 95-98

9. I. Youm, J. Sarr, M. Sall, A. Ndiaye, and Kane MM, Analysis of wind data and wind energy potential along the northern coast of Senegal, Rev. Energ. Ren. 8, 95-108 (2005)

10. B. Ould Bilal, C.M.F. Kébé, V. Sambou, M. Ndongo, P.A. Ndiaye, Étude et modélisation du potentiel éolien du site de Nouakchott, Journal des Sciences Pour l'Ingénieur 9, 28-34 (2008)

11. C.M.F. Kébé, V. Sambou, B. Ould Bilal, P.A. Ndiaye, S. Lo, Évaluation du potentiel éolien du site de Gandon dans la région nord du Sénégal, International Metrology Conference CAFMET (2008), pp. 1-6

12. B. Ould Bilal, V. Sambou, C.M.F. Kébé, M. Ndongo, P.A. Ndiaye, Study and modelling of solar and wind power potential: Comparative Study of three sites in the West Coast of Africa, World Renewable Energy Congress X, Glasgow, Scotland (2008)

13. B. Ould Bilal, M. Ndongo, V. Sambou, P.A. Ndiaye, C.M. Kébé, Diurnal characteristics of the wind potential along the North-western coast of Senegal, Int. J. Phys. Sci. 6, 7950-7960 (2011)

14. B. Ould Bilal, P.A. Ndiaye, C.M.F. Kébé, A. Diay Évaluation du potentiel éolien des sites de Kayar et de Potou Application au choix d'une éolienne adaptée au site, Journal Des Sciences pour l'Ingénieur (JSPI) 12, 33-41 (2010)
15. M. Gokcek, A. Bayulken, S. Bekdemir, Investigation of wind characteristics and wind energy potential in Kirklareli, Turkey, Renew. Energ. 32, 1739-1752 (2007)

16. N.C. Ali, A statistical analysis of wind power density based on the Weibull and Rayleigh models at the southern region of Turkey, Renew. Energ. 29, 593-604 (2003)

17. J.V. Seguro, T.W, Lambert. Modern estimation of the parameters of the Weibull wind speed distribution for wind energy analysis, J. Wind Eng. Ind. Aerodyn. 85, 75-84 (2000)

18. W. Zhou, H. Yang, Z. Fang, Wind power potential and characteristics analysis of the Pearl River Delta Region, Renew. Energ. 31, 739-753 (2006)

19. A.M. Omer, On the wind energy resources of Sudan, Renew. Sust. Energ. Rev. 12, 2117-2139 (2008)

20. B.S. Borowy, Z.M. Salameh, Optimum photovoltaic array size for a hybrid Wind/PV system, IEEE Trans. Energ. Convers. 3, 482-488 (1994)

21. G.L. Johnson, Wind Energy Systems (Prentice-Hall, ltic., N.J, 1985), Chap. 4

22. H.S. Bagiorgas, M.N. Assimakopoulos, D. Theoharopoulos, D. Matthopoulos, G.K. Mihalakakou, Electricity generation using wind energy conversion systems in the area of Western Greece, Energ. Convers. Manag. 48, 1640-1655 (2007)

23. BWE, Market servey: Wind Turbine $25 \mathrm{~kW}-5 \mathrm{MW}$ with measurement results, Expert reports, Wind Energy, 2006 